\title{
Comparative Study on Conventional Sintering with Microwave Sintering and Vacuum Sintering of $\mathrm{Y}_{2} \mathrm{O}_{3}-\mathrm{Al}_{2} \mathrm{O}_{3}-\mathrm{ZrO}_{2}$ Ceramics
}

\author{
Mayur Shukla1,2, Sumana Ghosh ${ }^{2 *}$, Nandadulal Dandapat², Ashis K. Mandal', \\ Vamsi K. Balla ${ }^{2}$ \\ ${ }^{1}$ Academy of Scientific and Innovative Research (AcSIR), CSIR-Central Glass and Ceramic Research Institute, \\ Kolkata, India \\ ${ }^{2}$ CSIR-Central Glass and Ceramic Research Institute (CSIR-CGCRI), Kolkata, India \\ Email: sumana@cgcri.res.in
}

Received 6 January 2016; accepted 12 February 2016; published 17 February 2016

Copyright $@ 2016$ by authors and Scientific Research Publishing Inc.

This work is licensed under the Creative Commons Attribution International License (CC BY).

http://creativecommons.org/licenses/by/4.0/

(c) (i) Open Access

\begin{abstract}
The present investigation demonstrated the comparative studies carried out on conventional, microwave and vacuum sintering of alumina added yttria stabilized zirconia (YSZ). The conventional, microwave and vacuum sintered specimens were characterized by density measurement, XRD, SEM with EDX analysis and hardness evaluation. Microwave sintering was proved to be the best efficient sintering technique with respect to energy and time savings. Enhanced densification was observed for the microwave and vacuum sintered specimens at lower temperatures compared to the conventionally sintered ones. Further, it was observed that the particle size had significant influence on the enhancement of densification. The microwave sintered specimen showed the highest hardness compared to conventional and vacuum sintered specimens.
\end{abstract}

Keywords

Ceramics, Zirconia, Sintering, Density, Microstructure, Hardness

\section{Introduction}

Zirconia $\left(\mathrm{ZrO}_{2}\right)$ ceramics possess excellent properties such as high fracture toughness, high hardness and wear ${ }^{*}$ Corresponding author.

How to cite this paper: Shukla, M., Ghosh, S., Dandapat, N., Mandal, A.K. and Balla, V.K. (2016) Comparative Study on Conventional Sintering with Microwave Sintering and Vacuum Sintering of $\mathrm{Y}_{2} \mathrm{O}_{3}-\mathrm{Al}_{2} \mathrm{O}_{3}-\mathrm{ZrO}_{2}$ Ceramics. Journal of Materials Science and Chemical Engineering, 4, 71-78. http://dx.doi.org/10.4236/msce.2016.42008 
resistance, chemical inertness, low thermal conductivity and ionic conductivity, which allows its use in a range of applications including precision ball valve balls, high-density ball-mill grinding media, rollers and guides for metal tube forming, thread guides, pump seals, oxygen sensors, and solid oxide fuel cell membranes. However, tailored microstructure can be produced through controlled processing of partially stabilized zirconia (PSZ) with alkaline earth or rare earth oxide additions e.g. yttria $\left(\mathrm{Y}_{2} \mathrm{O}_{3}\right)$ so that transformation toughening can be achieved by tetragonal $\mathrm{ZrO}_{2}\left(\mathrm{t}-\mathrm{ZrO}_{2}\right)$ to monoclinic $\mathrm{ZrO}_{2}\left(\mathrm{~m}-\mathrm{ZrO}_{2}\right)$ phase transformation [1].

Recently, interest has been growing in the use of microwave energy to sinter ceramic compacts. In conventional thermal processing, energy is transferred to the material through conduction and radiation of heat from the surface. In contrast, microwave energy is delivered directly to the material through molecular interaction with the electromagnetic field. This interaction leads to various beneficial effects, which includes rapid volumetric heating, shorter sintering times, lower sintering temperatures and selective heating. The energy savings are in the range of $25 \%$ - 95\%. In addition, it is well established that densification of a variety of ceramic materials is enhanced by microwave sintering. Higher densities are being achieved by microwave heating at lower temperatures than that obtained by conventional radiant heating [2]-[7]. Conventional sintering of zirconia at high temperatures above $1600^{\circ} \mathrm{C}$ results in tetragonal to monoclinic phase transformation on cooling, leading to destruction of the specimen on account of grain enlargement. Sintering at low oxygen partial pressure causes stabilization of high temperature phase of zirconia similar to oxide additives such as $\mathrm{Y}_{2} \mathrm{O}_{3}, \mathrm{CaO}$, MgO, etc. Therefore, stabilization of tetragonal zirconia as well as high densification can be achieved by vacuum sintering method [8] [9].

Few studies were made to investigate the vacuum sintering effect on the phase composition and properties of ceramics compared to the conventionally sintered ones. It was reported that vacuum sintering of plasma-chemical 3 wt.\% yttria added zirconia at high temperatures stabilized the tetragonal phase of zirconia in association with obtaining high densification [10] [11]. Sablina et al. [12] showed that density increased with increasing temperature and tetragonal to monoclinic phase transformation did not take place on cooling in case of vacuum sintering of $\mathrm{ZrO}_{2}-\mathrm{Y}_{2} \mathrm{O}_{3}$ and $\mathrm{ZrO}_{2}-\mathrm{Y}_{2} \mathrm{O}_{3}-\mathrm{Al}_{2} \mathrm{O}_{3}$ based ceramic specimens. Wilson and Kunz [13] evaluated microwave sintering of partially stabilized $\mathrm{ZrO}_{2}$. They placed $\mathrm{ZrO}_{2}$ material in $\mathrm{SiC}$ susceptors that absorbed microwave energy and transferred heat to the specimen. After initial heating, the $\mathrm{ZrO}_{2}$ material could then absorb microwave energy and got heated. They showed that cracking of the $\mathrm{ZrO}_{2}$ material occurred by ultra-rapid heating and observed similar physical properties for conventional and microwave sintered $\mathrm{ZrO}_{2}$. Janney et al. [14] sintered $8 \mathrm{~mol} \%$ ytttria stabilized zirconia (YSZ) using SiC rod as susceptor. Further, Nightingale and Dunne [15] studied the density and grain growth of 3Y-TZP sintered in the conventional and microwave ovens. Sintering of zirconia ceramics using microwaves of various frequencies $(2.45-60 \mathrm{GHz})$ has been already studied [5]. Goldstein et al. [16] sintered YSZ by microwave directly. They indicated that microwave sintered specimen had a smaller grain size. Upadhyaya et al. [17] studied sintering and grain growth of 3Y-TZP and 3Y-TZP with the addition of $\mathrm{TiO}_{2}$ and $\mathrm{MnO}_{2}$ in order to improve the microwave coupling at a given temperature. Wang et al. [18] used microwave/conventional hybrid heating technique for various ceramics including zirconia. However, grain growth was enhanced during microwave/conventional hybrid heating compared with conventional heating and thereby, suggesting acceleration of the diffusion processes by microwave/conventional hybrid heating. Matsui et al. [19] reported that small amount of $\mathrm{Al}_{2} \mathrm{O}_{3}$ enhanced the densification rate because of the decrease in the activation energy with the change in the diffusion mechanism from grain boundary diffusion (GBD) to volume diffusion (VD).

In the present investigation, comparative studies have been performed between conventional, microwave and vacuum sintering of alumina added $8 \mathrm{wt}$.\% YSZ ceramics. The objective of this paper is to get full dense YSZ at lower temperature with superior hardness.

\section{Experimental}

Commercial 8 mol\% $\mathrm{Y}_{2} \mathrm{O}_{3}-\mathrm{ZrO}_{2}$ powder (YSZ, Metallizing Equipment Co. Private Limited, India, particle size $45 \pm 10 \mu \mathrm{m})$ was mixed with $0.5 \%, 1 \%, 1.5 \%$ and $2 \%$ of alumina $\left(\mathrm{Al}_{2} \mathrm{O}_{3}\right.$, Alcoa, USA; 99.99\% purity). Alumina was added to enhance the sintering of $\mathrm{YSZ}$. YSZ and $\mathrm{Al}_{2} \mathrm{O}_{3}$ Powders were milled in a planetary mill to obtain homogenous powder mixture. Powders were then isostatically pressed (EPSI NV, SO, 10,036 Belgium) at 150 MPa to produce disk-shaped green compacts. The green powder compacts were dried at $100^{\circ} \mathrm{C}$ for $5 \mathrm{~h}$ and calcined in an electrical furnace (ELECTROHEAT, Model No.EN170QT, Naskar \& Co., Howrah, India) at $1200^{\circ} \mathrm{C}$ 
for $1 \mathrm{~h}$, then cut and finally sintered at $1600^{\circ} \mathrm{C}$ for various period of time ranging from $2 \mathrm{~h}$ to $10 \mathrm{~h}$. Heating and cooling cycle has been shown in Figure 1.

Another set of specimens were sintered in a microwave furnace (Enerzi Microwave Systems Pvt. Limited, Bangalore, India) at $1500^{\circ} \mathrm{C}$ for $20 \mathrm{~min}$. Heating and cooling time was $25^{\circ} \mathrm{C} / \mathrm{min}$. A multimode microwave furnace with a magnetron having frequency of $2.45 \mathrm{GHz}$ and maximum output power of $3 \mathrm{~kW}$ was used for the sintering. SiC powder was used as a susceptor to initiate coupling of microwave with the specimen. The specimens were placed in an alumina disc insulated by microwave transparent casket insulating box. The top cover of the insulating box had a hole of $20 \mathrm{~mm}$ diameter to monitor temperature through a non-contact IR pyrometer. Temperature measurement accuracy was $\pm 0.3 \%$ of the measured value $+1^{\circ} \mathrm{C}$ with adjustable emissivity $(\varepsilon: 0.1$ 1.0). Third set of specimens were sintered in a vacuum furnace (Hindhivac Private Limited, Bangalore, India) with a vacuum of $5 \times 10^{-6} \mathrm{mbar}$ at $1500^{\circ} \mathrm{C}$ for $20 \mathrm{~min}$. Heating and cooling rate was $10^{\circ} \mathrm{C} / \mathrm{min}$ and $7^{\circ} \mathrm{C} / \mathrm{min}$, respectively. Different temperature programs for conventional, microwave and vacuum sintering were selected to establish the superiority of the microwave and vacuum sintering techniques compared to conventional sintering technique.

The surfaces of sintered specimens were ground using a grinding machine (BAINLINE Belt Linishing machine, Chennai Metco. Limited, Chennai, India) and then polished in a polishing machine (Leco Corporation, USA) with $6 \mu \mathrm{m}, 3 \mu \mathrm{m}$ and $0.25 \mu \mathrm{m}$ diamond pastes (Buehler USA). The bulk density of the sintered specimen was measured by Archimedes' principle. Polished specimens were thermally etched at $1300^{\circ} \mathrm{C}$ for $30 \mathrm{~min}$ in an electrical furnace to reveal the microstructure. In order to examine the phase assemblages of the densified bodies X-ray diffraction was performed (PW 1710, Philips Research Laboratory, Eindhoven, Netherlands) with Cu K $\alpha$ radiation (45 kV, $35 \mathrm{~mA})$. Microstructural observations were performed by scanning electron microscopy (SEM) (Phenom Pro-X, Netherlands) and elemental composition was determined by energy dispersive X-ray (EDX) analysis (Phenom Pro-X, Netherlands). Microhardness was evaluated by a Vickers hardness tester (ESEWAY, 410 series, Bowers group, U.K.) at a load of $100 \mathrm{~g}$ with $30 \mathrm{~s}$ loading/unloading time. For a particular type of specimen, five specimens were examined. Considerable numbers of data were taken to avoid any error in hardness measurement.

Similarly, commercial nano-sized 8 wt. $\% \mathrm{Y}_{2} \mathrm{O}_{3}-\mathrm{ZrO}_{2}$ powder (YSZ, TOSOH CORPORATION, Japan, particle size $40 \pm 20 \mathrm{~nm}$ ) was conventionally sintered at $1450^{\circ} \mathrm{C}$ for $2 \mathrm{~h}$ in a conventional furnace. Heating rate was $3^{\circ} \mathrm{C} / \mathrm{min}$ and cooling rate was $2^{\circ} \mathrm{C} / \mathrm{min}$ up to $1000^{\circ} \mathrm{C}$ and $4^{\circ} \mathrm{C} / \mathrm{min}$ up to $600^{\circ} \mathrm{C}$. Furnace cooling to room temperature was conducted after $600^{\circ} \mathrm{C}$. The sintered nano-YSZ specimen was subsequently characterized in the same manner. Conventional sintering of nano-YSZ specimen was conducted in order to establish the effect of particle size.

\section{Results and Discussion}

Figure 1 shows that conventional sintering method required $\sim 13 \mathrm{~h}$ for the total sintering operation of $0.5 \mathrm{wt} . \%$ alumina added YSZ specimen whereas total processing time was $\sim 3 \mathrm{~h}$ for the microwave sintered specimen. Total processing time for vacuum sintered similar specimen was $\sim 7 \mathrm{~h}$, which was intermediate among the three processing techniques. Figure 2(a) shows the density of $\mathrm{YSZ}$ sintered at $1600^{\circ} \mathrm{C}$ for different period of time with the increase of alumina addition. It was observed that highest density could be achieved by the addition of 0.5 wt. $\% \mathrm{Al}_{2} \mathrm{O}_{3}$ to $\mathrm{YSZ}$. Therefore, $0.5 \mathrm{Al}_{2} \mathrm{O}_{3}-\mathrm{YSZ}$ composition was selected as optimum composition for continuing further investigation. Figure 2(b) shows the density values for $0.5 \mathrm{wt} \% \mathrm{Al}_{2} \mathrm{O}_{3}$ added $\mathrm{YSZ}$ specimen at $1600^{\circ} \mathrm{C}$ as a function of soaking time. The $0.5 \mathrm{Al}_{2} \mathrm{O}_{3}$-YSZ specimen had $80 \%$ density after sintering at $1600^{\circ} \mathrm{C}$ for $10 \mathrm{~h}$ duration whereas $75 \%$ density was obtained for the similar specimen sintered at $1600^{\circ} \mathrm{C}$ for $8 \mathrm{~h}$. The microwave sintered $0.5 \mathrm{Al}_{2} \mathrm{O}_{3}$-YSZ specimen at $1500^{\circ} \mathrm{C}$ for 20 min showed $75 \%$ density while it was $70 \%$ density in the case of vacuum sintered $\left(1500^{\circ} \mathrm{C}, 20 \mathrm{~min}\right) 0.5 \mathrm{Al}_{2} \mathrm{O}_{3}-\mathrm{YSZ}$ specimen. It can be said that both microwave and vacuum sintering resulted enhanced densification at lower sintering temperature within shorter processing time leading to energy and time savings. However, highest energy and time savings was observed with the microwave sintering operation. Further, the density of vacuum sintered $0.5 \mathrm{Al}_{2} \mathrm{O}_{3}$-YSZ specimen was comparable with that of the microwave sintered $0.5 \mathrm{Al}_{2} \mathrm{O}_{3}$-YSZ specimen.

Figure 3 represents the XRD patterns of conventional, microwave and vacuum sintered $0.5 \mathrm{Al}_{2} \mathrm{O}_{3}-\mathrm{YSZ}$ specimens. The crystalline phases were identified as tetragonal zirconia $\left(\mathrm{t}-\mathrm{ZrO}_{2}\right)$, monoclinic zirconia $\left(\mathrm{m}-\mathrm{ZrO}_{2}\right)$, $\mathrm{Y}_{2} \mathrm{O}_{3}$ and $\mathrm{Al}_{2} \mathrm{O}_{3}$ in all the cases. The major crystalline phase was $\mathrm{t}-\mathrm{ZrO}_{2}$ whereas $\mathrm{m}-\mathrm{ZrO}_{2}, \mathrm{Y}_{2} \mathrm{O}_{3}$ and $\mathrm{Al}_{2} \mathrm{O}_{3}$ were 


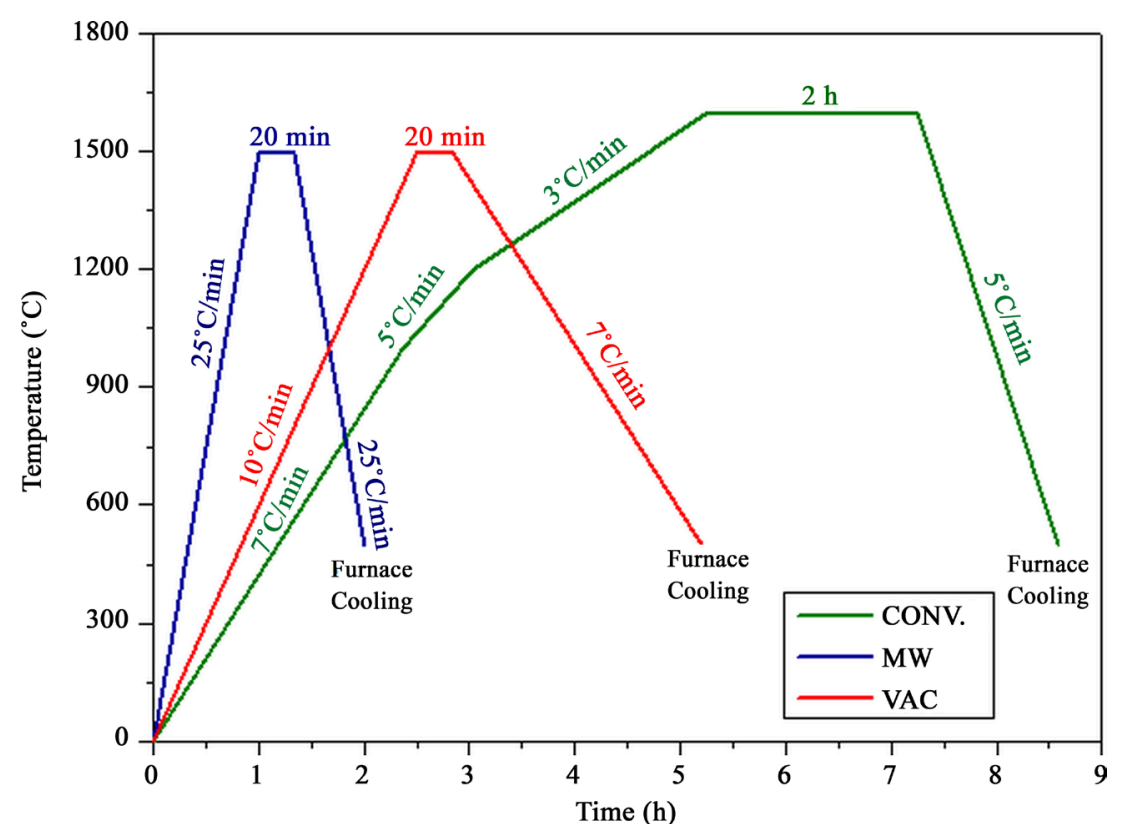

Figure 1. Temperature versus time plots for conventional, microwave and vacuum sintering operations.
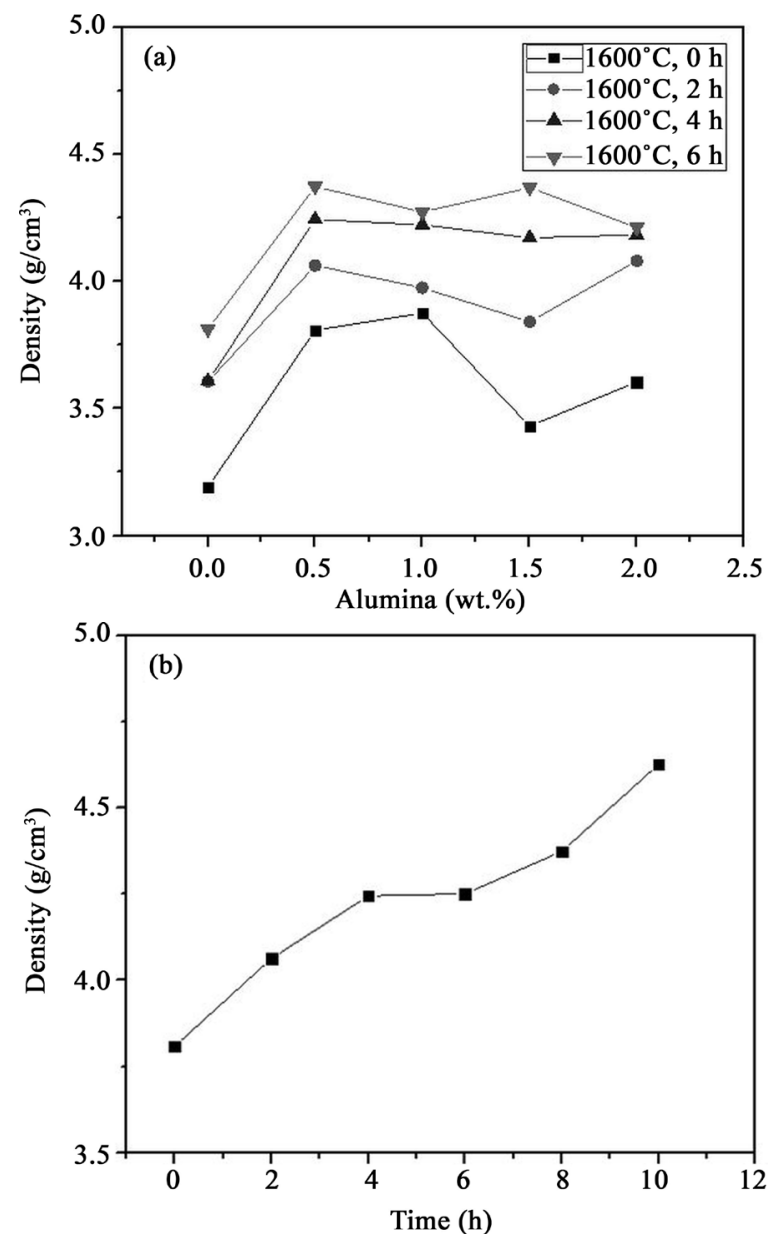

Figure 2. (a) Density of $\mathrm{YSZ}$ sintered at $1600^{\circ} \mathrm{C}$ for different period of time as a function of alumina addition and (b) density versus dwell time plot for YSZ with 0.5 wt. \% alumina addition. 


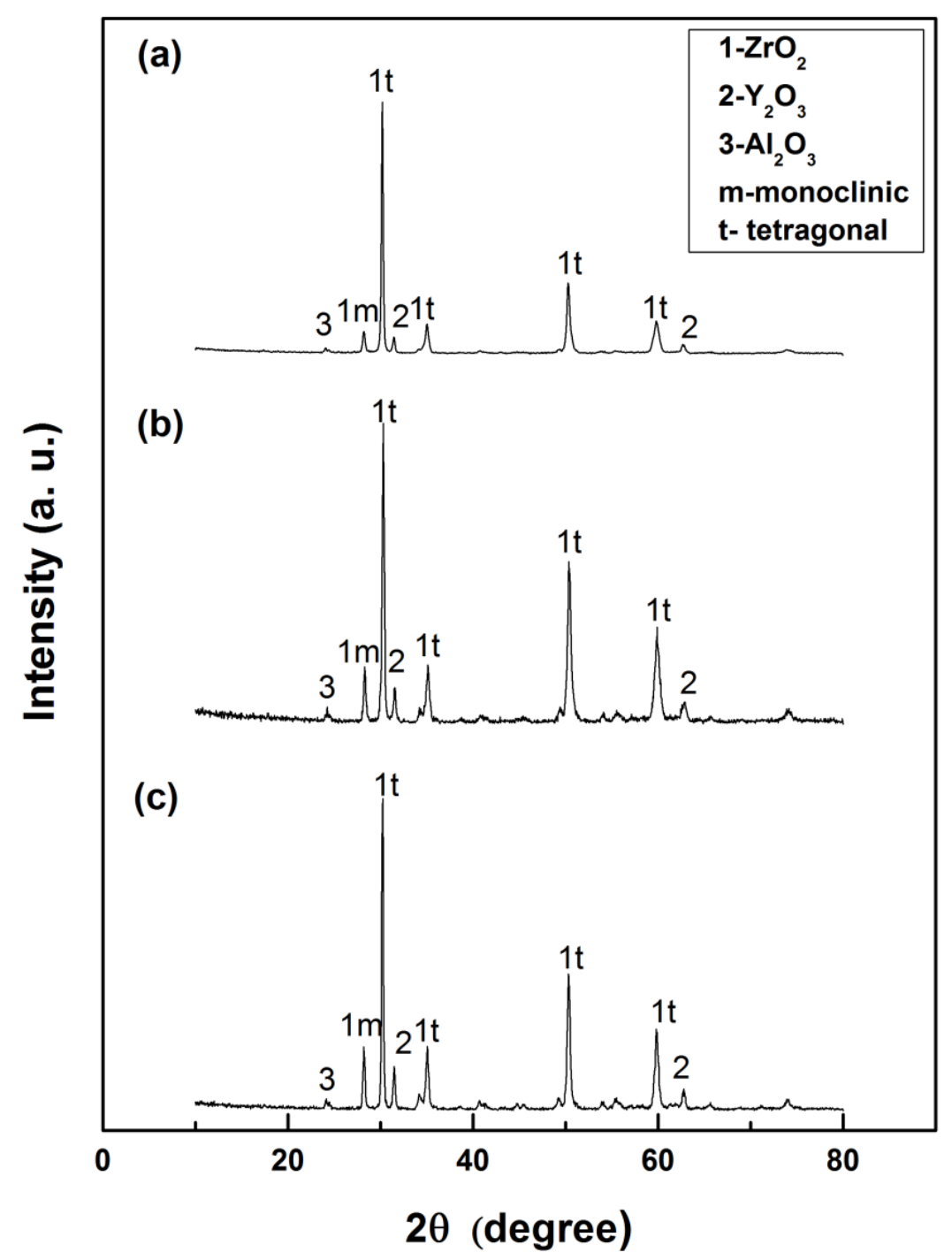

Figure 3. XRD analysis of (a) conventional, (b) microwave and (c) vacuum sintered $0.5 \mathrm{Al}_{2} \mathrm{O}_{3}-\mathrm{YSZ}_{\text {specimens. }}$

present as minor phases. Therefore, transformation toughening can be obtained for the sintered specimen as a consequence of $\mathrm{t}-\mathrm{ZrO}_{2}$ to $\mathrm{m}-\mathrm{ZrO}_{2}$ phase transformation. Figure 4 shows the microstructures of conventional, microwave and vacuum sintered $0.5 \mathrm{Al}_{2} \mathrm{O}_{3}$-YSZ specimens.

Conventionally sintered specimen demonstrated highest grain growth having grain size of $2.5 \pm 0.25 \mu \mathrm{m}$ (Figure 4(a), Figure 4(b)). The microwave sintered specimen had finest grain size of $0.8 \pm 0.1 \mu \mathrm{m}$ (Figure 4(c), Figure 4(d)). Whereas the vacuum sintered specimen showed a grain size of $1.2 \pm 0.2 \mu \mathrm{m}$ (Figure 4(e), Figure 4(f)). In addition, significant difference in the morphologies of the conventional, microwave and vacuum sintered specimens was observed. The microwave sintered specimen displayed uniform grain size. In contrast, the conventional and vacuum sintered specimens showed non-uniformity in the grain size.

Present study showed that $100 \%$ dense YSZ specimen was achieved by $2 \mathrm{~h}$ soaking at $1450^{\circ} \mathrm{C}$ in the conventional route through particle size tuning of the starting powder from micron-size to nanometer-size range. Figure 5(a) shows the typical XRD analysis of nano-YSZ specimen conventionally sintered at $1450^{\circ} \mathrm{C}$ for $2 \mathrm{~h}$, which was identical to those obtained for conventional, microwave and vacuum sintered micron-sized 0.5 $\mathrm{Al}_{2} \mathrm{O}_{3}$-YSZ specimens. The total processing time was analogous to that maintained for conventional sintering of micron-sized $0.5 \mathrm{Al}_{2} \mathrm{O}_{3}$-YSZ specimen. The SEM image and corresponding EDX analysis have been shown in Figure 5(b). The SEM microstructure showed that the grain morphology of nano-YSZ specimen was spherical. The EDX pattern confirmed the presence of $\mathrm{Zr}$ and $\mathrm{O}$ elements only. 
Table 1 shows the density and hardness values for conventional, microwave and vacuum sintered $0.5 \mathrm{Al}_{2} \mathrm{O}_{3^{-}}$ YSZ specimens (micron-sized) and conventionally sintered nano-sized YSZ specimen. Conventionally sintered nano-sized YSZ specimen exhibited 100\% density at lowest temperature with highest hardness i.e. $1345 \pm 25$ VHN (13.19 $\pm 0.25 \mathrm{GPa})$. The hardness of conventionally sintered $0.5 \mathrm{Al}_{2} \mathrm{O}_{3}-\mathrm{YSZ}$ specimen for $10 \mathrm{~h}$ duration was $660 \pm 20 \mathrm{VHN}(6.47 \pm 0.20 \mathrm{GPa})$ while it was $433 \pm 15 \mathrm{VHN}(4.25 \pm 0.15 \mathrm{GPa})$ in case of similar specimen conventionally sintered for $8 \mathrm{~h}$. The hardness of microwave sintered $\left(1500^{\circ} \mathrm{C}, 20 \mathrm{~min}\right) 0.5 \mathrm{Al}_{2} \mathrm{O}_{3}-\mathrm{YSZ}$ specimen was $440 \pm 17 \mathrm{VHN}(4.32 \pm 0.17 \mathrm{GPa})$ whereas it was $417 \pm 18 \mathrm{VHN}(4.09 \pm 0.18 \mathrm{GPa})$ in case of vacuum sintered $\left(1500^{\circ} \mathrm{C}, 20 \mathrm{~min}\right)$ specimen.
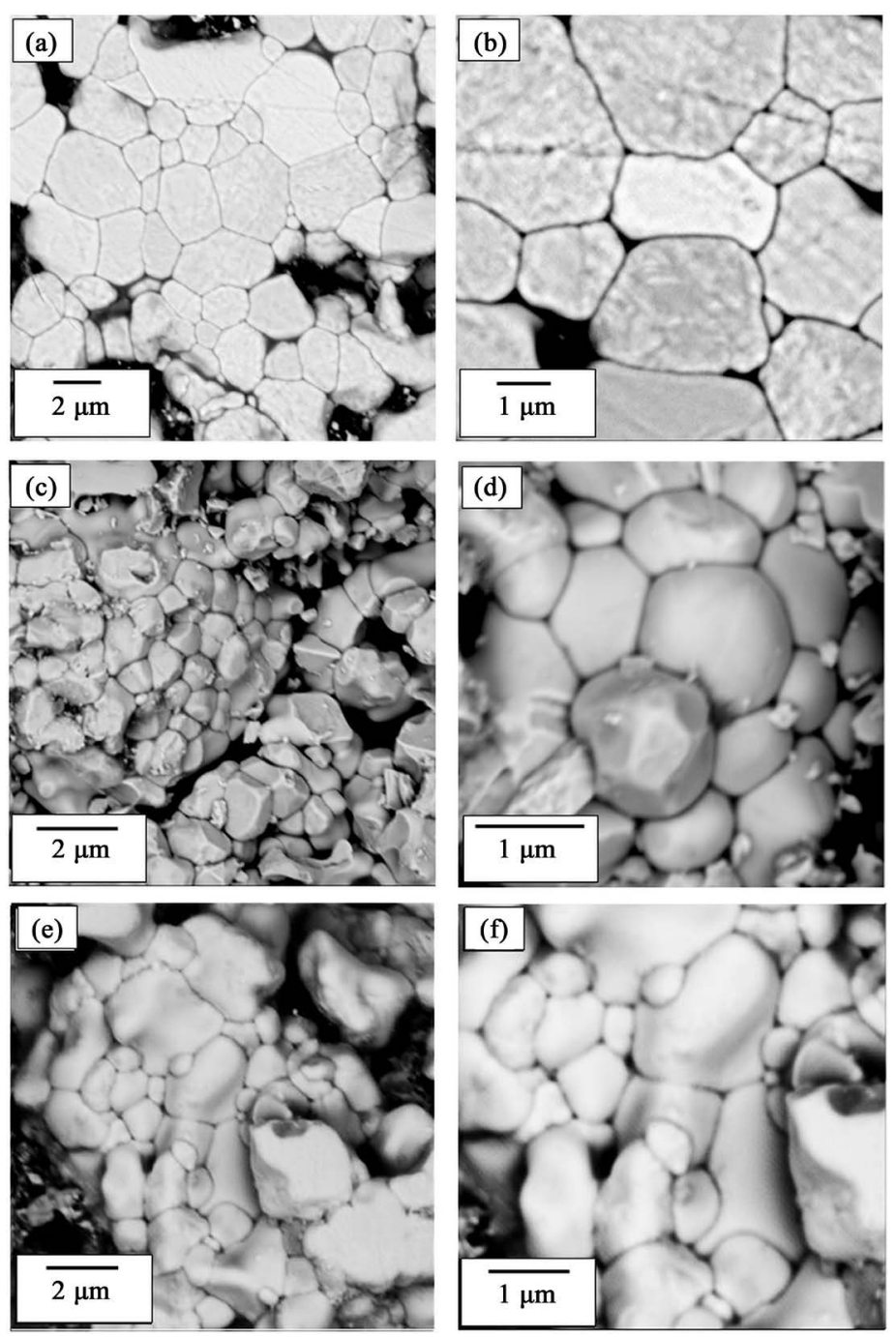

Figure 4. SEM images of (a)-(b) conventional, (c)-(d) microwave and (e)-(f) vacuum sintered $0.5 \mathrm{Al}_{2} \mathrm{O}_{3}-\mathrm{YSZ}$ specimens.

Table 1. Properties of conventional, microwave and vacuum sintered zirconia.

\begin{tabular}{ccccc}
\hline \multirow{2}{*}{ Processing Method } & \multicolumn{4}{c}{ Properties } \\
\cline { 2 - 5 } & Particle Size & Density $\left(\mathrm{g} / \mathrm{cm}^{3}\right)$ & Hardness $($ VHN) & Hardness (GPa) \\
\hline Conventional $\left(1600^{\circ} \mathrm{C}, 10 \mathrm{~h}\right)$ & $45 \pm 10 \mu \mathrm{m}$ & $4.8(80 \%)$ & $660 \pm 20$ & $6.47 \pm 0.20$ \\
Conventional $\left(1600^{\circ} \mathrm{C}, 8 \mathrm{~h}\right)$ & $45 \pm 10 \mu \mathrm{m}$ & $4.5(75 \%)$ & $433 \pm 15$ & $4.25 \pm 0.15$ \\
Microwave $\left(1500^{\circ} \mathrm{C}, 20 \mathrm{~min}\right)$ & $45 \pm 10 \mu \mathrm{m}$ & $4.5(75 \%)$ & $440 \pm 17$ & $4.32 \pm 0.17$ \\
Vacuum $\left(1500^{\circ} \mathrm{C}, 20 \mathrm{~min}\right)$ & $45 \pm 10 \mu \mathrm{m}$ & $4.2(70 \%)$ & $417 \pm 18$ & $4.09 \pm 0.18$ \\
Conventional $\left(1450^{\circ} \mathrm{C}, 2 \mathrm{~h}\right)$ & $40 \pm 20 \mathrm{~nm}$ & $6.0(100 \%)$ & $1345 \pm 25$ & $13.19 \pm 0.25$ \\
\hline
\end{tabular}




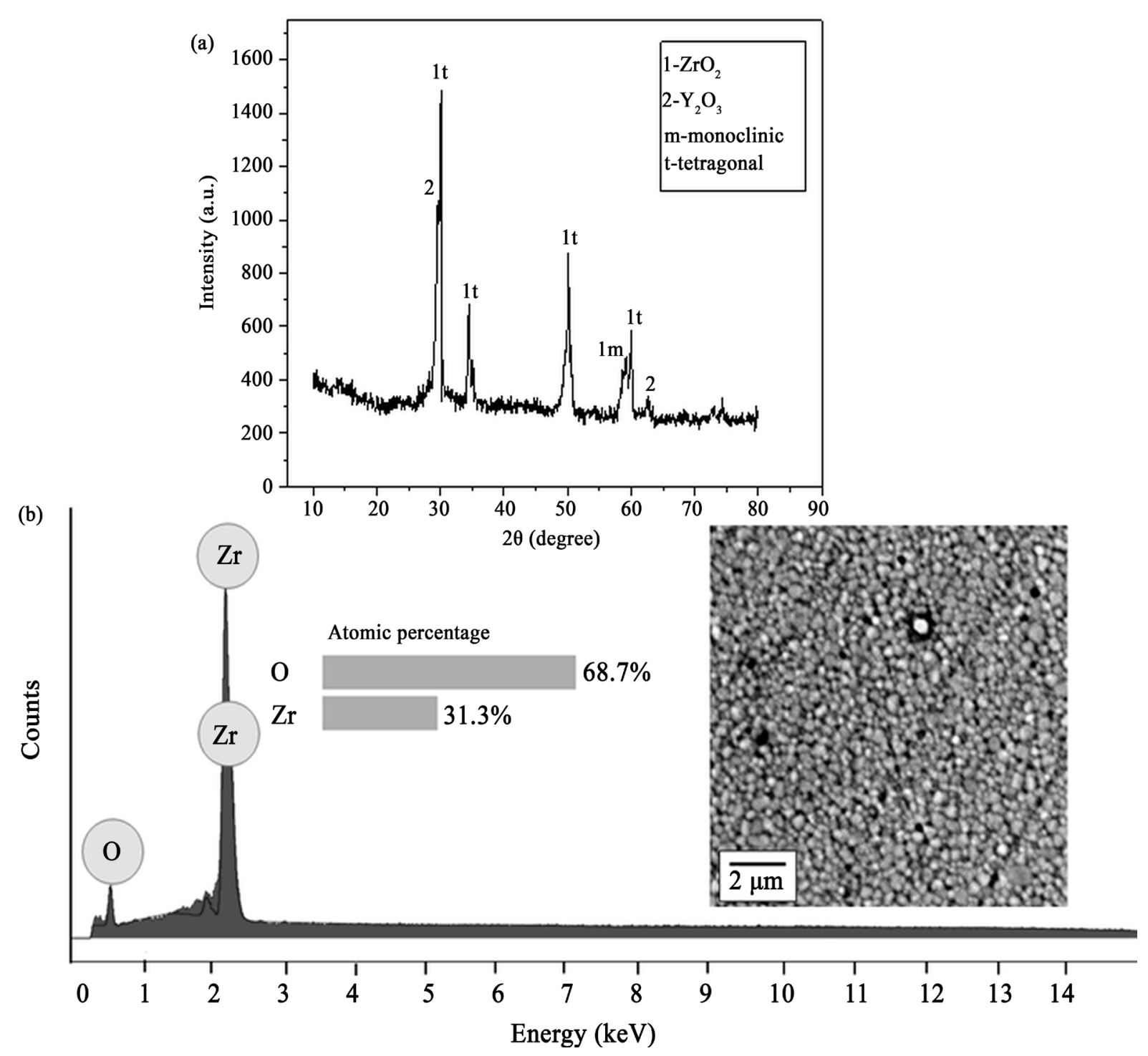

Figure 5. Typical (a) XRD plot and (b) EDX pattern in association with SEM image (shown in inset) of sintered nano-YSZ specimen.

\section{Conclusion}

The present investigation showed that microwave and vacuum sintering techniques offered enhanced sintering at lower temperatures compared to conventional sintering technique in case of the micron-sized $0.5 \mathrm{Al}_{2} \mathrm{O}_{3}$-YSZ specimen. However, microwave sintering technique appeared as the best sintering technique in comparison to the conventional and vacuum sintering techniques. Further, conventional sintering of nano-YSZ specimen imparted $100 \%$ density at $1450^{\circ} \mathrm{C}$ for $2 \mathrm{~h}$ soaking. In contrast, conventionally sintered micron-sized $0.5 \mathrm{Al}_{2} \mathrm{O}_{3}-\mathrm{YSZ}$ specimen revealed $80 \%$ density after $10 \mathrm{~h}$ soaking at $1600^{\circ} \mathrm{C}$. The current study also established the particle size effect on densification of the conventionally sintered YSZ specimen. Thus, the present study showed some possible means through which hard zirconia based ceramics can be manufactured for suitable applications in dentistry.

\section{Acknowledgements}

The present work was financially supported by CSIR, India under 12 FYP network project titled "Very High Power Microwave Tubes: Design and Development Capabilities (MTDDC)”, Grant No. PSC0101. 


\section{References}

[1] Hannink, R.H.J., Kelly, P.M. and Muddle, B.C. (2000) Transformation Toughening in Zirconia-Containing Ceramics. Journal of the American Ceramic Society, 83, 461-487. http://dx.doi.org/10.1111/j.1151-2916.2000.tb01221.x

[2] Sheppard, L.M. (1988) Manufacturing Ceramics with Microwaves: The Potential for Economical Production. American Ceramic Society Bulletin, 67, 1656-1661.

[3] Katz, J.D. (1992) Microwave Sintering of Ceramics. Annual Review of Materials Science, 22, 153-170. http://dx.doi.org/10.1146/annurev.ms.22.080192.001101

[4] Clark, D.E., Folz, D.C., Schulz, R.L., Fathi, Z. and Cozzi, A.D. (1993) Recent Developments in Microwave Processing of Ceramics. Materials Research Bulletin, 18, 41-46.

[5] Thostenson, E.T. and Chou, T.W. (1999) Microwave Processing: Fundamentals and Applications. Composites Part A: Applied Science and Manufacturing, 30, 1055-1071. http://dx.doi.org/10.1016/S1359-835X(99)00020-2

[6] Weller, M. and Schubert, H. (1986) Internal Friction, Dielectric Loss, and Ionic Conductivity of Tetragonal $\mathrm{ZrO}_{2}-3 \%$ $\mathrm{Y}_{2} \mathrm{O}_{3}$ (Y-TZP). Journal of the American Ceramic Society, 69, 573-577.

[7] Kenkre, V.M. (1991) Theory of Microwave Interactions with Ceramics. Ceramic Transactions, 21, 69-80.

[8] Ruh, R. and Garrett, H.J. (1967) Non-Stoichiometry of $\mathrm{ZrO}_{2}$ and Its Relation to Tetragonal-Cubic Inversion in $\mathrm{ZrO}_{2}$ Journal of the American Ceramic Society, 50, 257-261. http://dx.doi.org/10.1111/j.1151-2916.1967.tb15099.x

[9] Ramaswamy, P. and Agrawal, D.C. (1987) Effect of Sintering Zirconia with Calcia in Very Low Partial Pressure of Oxygen. Journal of Materials Science, 22, 1243-1248. http://dx.doi.org/10.1007/BF01233116

[10] Savchenko, N.L., Sablina, T.Y., Poletika, T.M., Artish, A.S. and Kul’kov, S.N. (1993) Phase Composition and Mechanical Properties of Zirconium Dioxide Based Ceramic Obtained by High Temperature Sintering in a Vacuum. Powder Metallurgy and Metal Ceramics, 32, 9-10.

[11] Savchenko, N.L., Sablina, T.Y., Poletika, T.M., Artish, A.S. and Kul'kov, S.N. (1994) High Temperature Vacuum Sintering of Plasmochemical Powders Based on $\mathrm{ZrO}_{2}$. Powder Metallurgy and Metal Ceramics, 33, 1-2.

[12] Sablina, T.Y., Savchenko, N.L., Mel'nikov, A.G. and Kul'kov, S.N. (1994) Vacuum Sintering of a Ceramic Based on Zirconium Dioxide. Glass and Ceramics, 51, 198-201. http://dx.doi.org/10.1007/BF00682584

[13] Wilson, J. and Kunz, S.M. (1988) Microwave Sintering of Partially Stabilized Zirconia. Journal of the American Ceramic Society, 71, C40-C41.

[14] Janney, M.A., Calhoun, C.L. and Kimrey, H.D. (1992) Microwave Sintering of Solid Oxide Fuel Cell Materials: I, Zirconia-8 mol\% Yttria. Journal of the American Ceramic Society, 75, 341-346. http://dx.doi.org/10.1111/j.1151-2916.1992.tb08184.x

[15] Nightingale, S.A., Dunne, D.P. and Worner, H.K. (1996) Sintering and Grain Growth of 3 mol\% Yttria Zirconia in a Microwave Field. Journal of Materials Science, 31, 5039-5043. http://dx.doi.org/10.1007/BF00355903

[16] Goldstein, A., Travitzky, N., Singurindy, A. and Kravchik, M.J. (1999) Direct Microwave Sintering of Yttria-Stabilized Zirconia at 2.45 GHz. Journal of the European Ceramic Society, 19, 2067-2072. http://dx.doi.org/10.1016/S0955-2219(99)00020-5

[17] Upadhyaya, D.D., Ghosh, A., Gurumurthy, K.R. and Prasad R. (2001) Microwave Sintering of Cubic Zirconia. Ceramics International, 27, 415-418. http://dx.doi.org/10.1016/S0272-8842(00)00096-1

[18] Wang, J., et al. (2006) Evidence for the Microwave Effect during Hybrid Sintering. Journal of the American Ceramic Society, 89, 1977-1984.

[19] Matsui, K., Yamakawa, T., Uehara, M., Enomoto, N. and Hojo, J. (2008) Sintering Mechanism of Fine Zirconia Powders with Alumina Added by Powder Mixing and Chemical Processes. Journal of Materials Science, 43, 27452753. http://dx.doi.org/10.1007/s10853-008-2493-5 